\title{
CAMBRIDGE STUDIES IN NINETEENTH-CENTURY \\ LITERATURE AND CULTURE
}

\author{
GENERAL EDITORS \\ Kate Flint, University of Southern California \\ Clare Pettitt, King's College London
}

Titles published

I. The Sickroom in Victorian Fiction: The Art of Being Ill MIRIAM BAILIN, Washington University

2. Muscular Christianity: Embodying the Victorian Age edited by donald E. Hall, California State University, Northridge

3. Victorian Masculinities: Manhood and Masculine Poetics in Early Victorian Literature and Art Herbert sussman, Northeastern University, Boston

4. Byron and the Victorians ANDREW ELFENBEIN, University of Minnesota

5. Literature in the Marketplace: Nineteenth-Century British Publishing and the Circulation of Books

edited by JOHN O. JORDAN, University of California, SANTA CRUZ and robert l. patten, Rice University, Houston

6. Victorian Photography, Painting and Poetry LINDSAY SMITH, University of Sussex

7. Charlotte Brontë and Victorian Psychology SALLY SHUTTLEWORTH, University of Sheffield

8. The Gothic Body: Sexuality, Materialism and Degeneration at the Fin de Siècle KELly HURLEY, University of Colorado at Boulder

9. Rereading Walter Pater William f. Shuter, Eastern Michigan University

IO. Remaking Queen Victoria edited by MARGaret homans, Yale University and ADrienne MUNich, State University of New York, Stony Brook

II. Disease, Desire, and the Body in Victorian Women's Popular Novels PAMELA K. GILBERT, University of Florida

I2. Realism, Representation, and the Arts in Nineteenth-Century Literature Alis on byerly, Middlebury College, Vermont

13. Literary Culture and the Pacific VANESSA SMITH, University of Sydney

I4. Professional Domesticity in the Victorian Novel: Women, Work and Home MONICA F. COHEN

15. Victorian Renovations of the Novel: Narrative Annexes and the Boundaries of Representation SUZANNE KEEN, Washington and Lee University, Virginia 
16. Actresses on the Victorian Stage: Feminine Performance and the Galatea Myth GAIL MARSHALL, University of Leeds

17. Death and the Mother from Dickens to Freud: Victorian Fiction and the Anxiety of Origin

CAROLYn DEVER, Vanderbilt University, Tennessee

18. Ancestry and Narrative in Nineteenth-Century British Literature: Blood Relations from Edgeworth to Hardy

sophie gilmartin, Royal Holloway, University of London

19. Dickens, Novel Reading, and the Victorian Popular Theatre DEBORAH VLOCK

20. After Dickens: Reading, Adaptation and Performance

JOHn GLAVIN, Georgetown University, Washington DC

2I. Victorian Women Writers and the Woman Question edited by nicola diane thompson, Kingston University, London

22. Rhythm and Will in Victorian Poetry MATTHEW CAMPBELL, University of Sheffield

23. Gender, Race, and the Writing of Empire: Public Discourse and the Boer War Paula m. KReBs, Wheaton College, Massachusetts

24. Ruskin's God

MICHAEL WHEELER, University of Southampton

25. Dickens and the Daughter of the House HILARY M. SCHOR, University of Southern California

26. Detective Fiction and the Rise of Forensic Science ronald r. Thomas, Trinity College, Hartford, Connecticut

27. Testimony and Advocacy in Victorian Law, Literature, and Theology jan-melissa schramm, Trinity Hall, Cambridge

28. Victorian Writing about Risk: Imagining a Safe England in a Dangerous World ELAINE FREEDGOOD, University of Pennsylvania

29. Physiognomy and the Meaning of Expression in Nineteenth-Century Culture LUCY HARTLEY, University of Southampton

30. The Victorian Parlour: A Cultural Study THAD logan, Rice University, Houston

3I. Aestheticism and Sexual Parody I840-1940 DENNis Denisoff, Ryerson University, Toronto

32. Literature, Technology and Magical Thinking, I880-I920 pamela thurschwell, University College London

33. Fairies in Nineteenth-Century Art and Literature NICOLA воWN, Birkbeck College, University of London

34. George Eliot and the British Empire NANCY HENRY, The State University of New York, Binghamton

35. Women's Poetry and Religion in Victorian England: Jewish Identity and Christian Culture

Cynthia scheinberg, Mills College, California

36. Victorian Literature and the Anorexic Body

AnNa KRUgovoy SILver, Mercer University, Georgia 
37. Eavesdropping in the Novel from Austen to Proust ANN GAYLIN, Yale University

38. Missionary Writing and Empire, I800-I860 ANNA JOHNSTON, University of Tasmania

39. London and the Culture of Homosexuality, I885-I9I4 матт соок, Keele University

40. Fiction, Famine, and the Rise of Economics in Victorian Britain and Ireland gordon Bigelow, Rhodes College, Tennessee

4I. Gender and the Victorian Periodical HILARY FRASER, Birkbeck College, University of London, JUDITH JOHNSTON and STEPHANie green, University of Western Australia

42. The Victorian Supernatural edited by NiCOLA BOWn, Birkbeck College, University of London, CAROLYN Burdett, London Metropolitan University, and pamela thurschwell, University College London

43. The Indian Mutiny and the British Imagination GaUTAM CHAKRAVARTy, University of Delhi

44. The Revolution in Popular Literature: Print, Politics and the People IAN HAYWOOD, Roehampton University of Surrey

45. Science in the Nineteenth-Century Periodical: Reading the Magazine of Nature GEOFFREY CANTOR, University of Leeds, GOWAN DAWSON, University of Leicester, GRAEME GOODAY, University of Leeds, RICHARD NOAKES, University of Cambridge, SALLY SHUTTLEWORTH, University of Sheffield, and JONATHAN R. TOPHAM, University of Leeds

46. Literature and Medicine in Nineteenth-Century Britain from Mary Shelley to George Eliot

JANIS MCLARREN CALDWELL, Wake Forest University

47. The Child Writer from Austen to Woolf edited by Christine alexander, University of New South Wales, and JULIET MCMASTER, University of Alberta

48. From Dickens to Dracula: Gothic, Economics, and Victorian Fiction GAIl turley houston, University of New Mexico

49. Voice and the Victorian Storyteller IVAN KREILKAMP, University of Indiana

50. Charles Darwin and Victorian Visual Culture JONATHAN SMith, University of Michigan-Dearborn

5I. Catholicism, Sexual Deviance, and Victorian Gothic Culture PATRICK R. O'MALLEY, Georgetown University

52. Epic and Empire in Nineteenth-Century Britain SIMON DENTITH, University of Gloucestershire

53. Victorian Honeymoons: Journeys to the Conjugal helena michie, Rice University

54. The Jewess in Nineteenth-Century British Literary Culture NADIA VALMAN, University of Southampton 
55. Ireland, India and Nationalism in Nineteenth-Century Literature JUlia wright, Dalhousie University

56. Dickens and the Popular Radical Imagination SALLY LEDGER, Birkbeck College, University of London

57. Darwin, Literature and Victorian Respectability GOWAN DAWSON, University of Leicester

58. 'Michael Field': Poetry, Aestheticism and the Fin de Siecle MARION THAIN, University of Birmingham

59. Colonies, Cults and Evolution: Literature, Science and Culture in NineteenthCentury Writing DAvid Amigoni, Keele University

6o. Realism, Photography and Nineteenth-Century Fiction DANIEL A. NOVAK, Louisiana State University

6I. Caribbean Culture and British Fiction in the Atlantic World, I780-I870 TIM watson, University of Miami

62. The Poetry of Chartism: Aesthetics, Politics, History MICHAEL SANDERS, University of Manchester

63. Literature and Dance in Nineteenth-Century Britain: Jane Austen to the New Woman CHERYL WILsON, Indiana University

64. Shakespeare and Victorian Women GaIl marshall, Oxford Brookes University

65. The Tragi-Comedy of Victorian Fatherhood VALERIE SANDERS, University of Hull

66. Darwin and the Memory of the Human: Evolution, Savages, and South America CANNON SCHMITT, University of Toronto

67. From Sketch to Novel: The Development of Victorian Fiction amanpal Garcha, Ohio State University

68. The Crimean War and the British Imagination stefanie markovits, Yale University

69. Shock, Memory and the Unconscious in Victorian Fiction JILL L. MATUS, University of Toronto

70. Sensation and Modernity in the I860s Nicholas Daly, University College Dublin

7I. Ghost-Seers, Detectives, and Spiritualists: Theories of Vision in Victorian Literature and Science SRDJAN SMAJIĆ, Furman University

72. Satire in an Age of Realism aAron matz, Scripps College, California

73. Thinking About Other People in Nineteenth-Century British Writing ADELA PINCH, University of Michigan

74. Tuberculosis and the Victorian Literary Imagination KATHERINe Byrne, University of Ulster, Coleraine 
75. Urban Realism and the Cosmopolitan Imagination in the Nineteenth Century: Visible City, Invisible World

tanya agathocleous, Hunter College, City University of New York

76. Women, Literature, and the Domesticated Landscape: England's Disciples of Flora, $1780-1870$

JUdith w. PAge, University of Florida, and elise L. Smith, Millsaps College, Mississippi

77. Time and the Moment in Victorian Literature and Society SUE ZEMKA, University of Colorado

78. Popular Fiction and Brain Science in the Late Nineteenth Century ANNe STILes, Washington State University

79. Picturing Reform in Victorian Britain JANiCE CARlisle, Yale University

80. Atonement and Self-Sacrifice in Nineteenth-Century Narrative JAN-MELISSA SCHRAMM, University of Cambridge

8I. The Silver Fork Novel: Fashionable Fiction in the Age of Reform edward copeland, Pomona College, California

82. Oscar Wilde and Ancient Greece IAIN ROss, Colchester Royal Grammar School

83. The Poetry of Victorian Scientists: Style, Science and Nonsense DANIEL BROWN, University of Southampton

84. Moral Authority, Men of Science, and the Victorian Novel ANne DeWITT, Princeton Writing Program

85. China and the Victorian Imagination: Empires Entwined ROSS G. FORMAN, University of Warwick

86. Dickens's Style edited by DANIEL TYLER, University of Oxford

87. The Formation of the Victorian Literary Profession RICHARD SALMON, University of Leeds

88. Before George Eliot: Marian Evans and the Periodical Press Fionnuala Dillane, University College Dublin

89. The Victorian Novel and the Space of Art: Fictional Form on Display DEHN GILMORE, California Institute of Technology

90. George Eliot and Money: Economics, Ethics and Literature DeRmot coleman, Independent Scholar

91. Masculinity and the New Imperialism: Rewriting Manhood in British Popular Literature, I870-I9I4 BRADLEY DEANE, University of Minnesota

92. Evolution and Victorian Culture edited by Bernard lightman, York University, Toronto, and BennetT ZON, University of Durham

93. Victorian Literature, Energy, and the Ecological Imagination allen macduffie, University of Texas, Austin

94. Popular Literature, Authorship and the Occult in Late Victorian Britain andrew mCCann, Dartmouth College, New Hampshire 
95. Women Writing Art History in the Nineteenth Century: Looking Like a Woman

HIlary FraSer, Birkbeck College, University of London

96. Relics of Death in Victorian Literature and Culture

DeBorah Lutz, Long Island University, C. W. Post Campus

97. The Demographic Imagination and the Nineteenth-Century City: Paris, London, New York

NiCHolas DAly, University College Dublin

98. Dickens and the Business of Death

ClaIRE WOOD, University of York

99. Translation as Transformation in Victorian Poetry

Annmarie Drury, Queens College, City University of New York

Ioo. The Bigamy Plot: Sensation and Convention in the Victorian Novel

maia mCaleavey, Boston College, Massachusetts

IOI. English Fiction and the Evolution of Language, I850-I9I4

WILL ABBERLEY, University of Oxford

IO2. The Racial Hand in the Victorian Imagination

Aviva briefel, Bowdoin College, Maine

I03. Evolution and Imagination in Victorian Children's Literature

JESSICA STRALEY, University of Utah

I04. Writing Arctic Disaster: Authorship and Exploration

ADRIANA CRACIUn, University of California, Riverside

I05. Science, Fiction, and the Fin-de-Siècle Periodical Press

Will taTtERSDill, University of Birmingham

106. Democratising Beauty in Nineteenth-Century Britain: Art and the Politics of Public Life

LUCY HARTLEY, University of Michigan

I07. Everyday Words and the Character of Prose in Nineteenth-Century Britain

jonathan farina, Seton Hall University, New Jersey

108. Gerard Manley Hopkins and the Poetry of Religious Experience

MARTIN DUBOIs, Newcastle University

I09. Blindness and Writing: From Wordsworth to Gissing

heather tilley, Birkbeck College, University of London

IIO. An Underground History of Early Victorian Fiction: Chartism, Radical Print Culture, and the Social Problem Novel

gregory vargo, New York University

III. Automatism and Creative Acts in the Age of New Psychology

Lind A M. Austin, Oklahoma State University

II2. Idleness and Aesthetic Consciousness, I8I5-I9oo

RICHARD ADELMAN, University of Sussex

II3. Poetry, Media, and the Material Body: Autopoetics in Nineteenth-Century Britain

Ashley miller, Albion College, Michigan

II4. Malaria and Victorian Fictions of Empire

Jessica howell, Texas A\&M University 
II5. The Brontës and the Idea of the Human: Science, Ethics, and the Victorian Imagination edited by ALEXANDRA LEWIs, University of Aberdeen

II6. The Political Lives of Victorian Animals: Liberal Creatures in Literature and Culture

ANNA FEUERSTEIN, University of Hawai'i-Manoa

II7. The Divine in the Commonplace: Recent Natural Histories and the Novel in Britain

Aмy кіnG, St John's University, New York

II8. Plagiarizing the Victorian Novel: Imitation, Parody, Aftertext ADAm ABRAHAm, Virginia Commonwealth University

II9. Literature, Print Culture, and Media Technologies, I880-I900: Many Inventions RICHARD MENKE, University of Georgia

I20. Aging, Duration, and the English Novel: Growing Old from Dickens to Woolf Jасов JEwusiak, Newcastle University

I2I. Autobiography, Sensation, and the Commodification of Identity in Victorian Narrative: Life upon the Exchange

SEAN GRASs, Rochester Institute of Technology

122. Settler Colonialism in Victorian Literature: Economics and Political Identity in the Networks of Empire

phillip steer, Massey University, Auckland

123. Mimicry and Display in Victorian Literary Culture: Nature, Science and the Nineteenth-Century Imagination

WILl AB BERLEY, University of Sussex

I24. Victorian Women and Wayward Reading: Crises of Identification

MARISA PALACios Knox, University of Texas Rio Grande Valley

I25. The Victorian Cult of Shakespeare: Bardology in the Nineteenth Century CHARLES LAPORTE, University of Washington

I26. Children's Literature and the Rise of 'Mind Cure': Positive Thinking and PseudoScience at the Fin de Siecle

Anne stiles, Saint Louis University, Missouri

127. Virtual Play and the Victorian Novel: The Ethics and Aesthetics of Fictional Experience

тімотну Gaо, Nanyang Technological University

128. Colonial Law in India and the Victorian Imagination

Leila neti, Occidental College, Los Angeles

I29. Convalescence in the Nineteenth-Century Novel: The Afterlife of Victorian Illness HOSANNA KRIENKE, University of Wyoming

I30. Stylistic Virtue and Victorian Fiction: Form, Ethics and the Novel MATTHEW SUSSMAN, The University of Sydney

13I. Scottish Women's Writing in the Long Nineteenth Century: The Romance of Everyday Life

JULIET SHIELDS, University of Washington 
132. Reimagining Dinosaurs in Late Victorian and Edwardian Literature: How the 'Terrible Lizard' Became a Transatlantic Cultural Icon RICHARD FALLON, The University of Birmingham

133. Decadent Ecology in British Literature and Art, I860-I9I0: Decay, Desire, and the Pagan Revival DENNIS DENISOFF, University of Tulsa

134. Vagrancy in the Victorian Age: Representing the Wandering Poor in NineteenthCentury Literature and Culture

alistair robinson, New College of the Humanities

135. Collaborative Writing in the Long Nineteenth Century: Sympathetic Partnerships and Artistic Creation

heather bozant witcher, Auburn University, Montgomery

136. Visual Culture and Arctic Voyages: Personal and Public Art and Literature of the Franklin Search Expeditions

EAvan o'dochartaigh, National University of Ireland Galway 